\title{
CAPITAL STRUCTURE DETERMINANTS IN SOUTH AFRICA: A PUANTILE REGRESSION APPROACH
}

\author{
Tendai Gwatidzo* \\ University of the Witwatersrand \\ tendai.gwatidzo@wits.ac.za \\ Miracle Ntuli\# \\ Mthokozisi Mlilo+ \\ University of the Witwatersrand \\ miracle.ntuli@wits.ac.za \\ University of the Witwatersrand \\ mthokozisi.mlilo@wits.ac.za \\ Received: May 2015 \\ Accepted: September 2015
}

\begin{abstract}
Using data on 239 listed South African firms and covering the period 1996-2010, we apply a quantile regression approach to investigate the effect of capital structure determinants on leverage. The paper's main contribution is to assess the effect of the predictor variables across the distribution of leverage. That is, does the effect of a capital structure determinant vary at different levels of leverage? With the exception of asset tangibility and age, whose effect increased with leverage, our results suggest that the importance of leverage determinants does not vary with leverage. This is an important result, as it suggests that for the case of South Africa, studies that estimate the correlates of leverage at the mean are still valid and appropriate.
\end{abstract}

Keywords

Capital structure, quantile regression, listed firms, South Africa.

*Prof T Gwatidzo is professor in the School of Economic and Business Sciences, University of the Witwatersrand, South Africa.

\#Prof M Ntuli is professor in the School of Economic and Business Sciences, University of the Witwatersrand, South Africa.

+Mr M Mlilo is a lecturer in the School of Economic and Business Sciences, University of the University of the Witwatersrand, South Africa. 


\section{INTRODUCTION}

Notable research effort has been expended on gaining a better understanding of firms' financing decisions. Most of the studies have, however, concentrated on developed economies, particularly the United States of America. See, for example, Titman and Wessels (1988), Shyam-Sunder and Myers (1999), Frank and Goyal (2003), Graham (1996), and Mackie-Mason (1990). More recently, studies have begun to focus on developing economies, including Africa's. See, for instance, Green and Mutenheri (2002), Abor and Biekpe (2005), Ezeoha (2008) and Gwatidzo and 0jah (2009). This is hardly surprising given that the studies are premised on capital structure theories which are conditional in applicability; they work better in some situations than others (Myers, 2003). This raises a need to test the theories in different environments and distinguish where they are more relevant. Such analyses require different econometric approaches as we gain confidence in results which are confirmed by different methods. To date, the approaches used in the literature have taken different forms, ranging from static to dynamic as well as mean-based (traditional OLS regressions) vs. distributional estimators (quantile regression analysis). Static capital structure studies examples are: Titman and Wessels (1988), Shyam-Sunder and Myers (1999), and MackieMason (1990), Green and Mutenheri (2002), Gwatidzo and 0jah (2009). Dynamic capital structure studies examples are: Drobetz and Wanzenried (2006), Flannery and Rangan (2006), Hovakimian and Li (2011), Yeh (2011), Reinhard and Li (2010), and Hass and Peeters (2006). However, only a few studies have used the distributional approach to investigate the determinants of capital structure in developing countries. One exception is Fattouh, Scaramozzino and Harris (2005), who used the approach to investigate capital structure determinants in South Korea. To the best of our knowledge, the approach has not yet been used in Africa, in general, and South Africa, in particular.

In light of the above lacuna, this paper carries out a quantile regression analysis of the determinants of capital structure among South African firms. More specifically, the study estimates a fixed effects quantile regression model of firm leverage using 1996-2010 panel data for listed South African firms. Quantile regression allows us to estimate conditional quantiles of firm leverage without making any distributional assumptions, given predictor variables. There are many advantages of using the quantile regression approach. First, unlike traditional mean-based estimators, this distributional estimator allows us to control for unobserved heterogeneity across the distribution of firm leverage (Canay, 2011). Generally, the technique is robust in handling firm heterogeneity, extreme values and outliers, which averts analytical problems of grouping small and large firms. Second, the estimator allows the effect of predictor variables to vary across quantiles of firm leverage, which distinguishes firms that are most affected by the predictor variables. This information answers the question whether more levered firms are differently affected by capital structure determinants compared to their less levered counterparts; enriching our understanding of the impact of capital structure determinants. In the process, we can tell whether the effect of a determinant can be rationalised by the same capital structure theory throughout the leverage distribution. Third, fixed effects potentially enable us to account for unobserved time invariant covariates, which improves the precision of estimates of our predictor variables (Canay, 2011).

Testing capital structure theories for South African firms is interesting for a number of reasons. Firstly, South Africa is considered an emerging African economy that is more developed than its African counterparts. For indicators that compare South Africa and the rest of the African countries see, for example, the World Development Indicators. 
For example, the Johannesburg Stock Exchange is the best stock exchange in Africa. This is based on indicators such as the number of firms listed on the exchange, market capitalisation and turnover ratio. See also the World Stock Exchanges online database on: www.world-stockexchanges.net. Furthermore, the lack of development in the capital markets in the rest of Africa and South Africa's superiority over the rest of Africa is also corroborated by Allen et al. (2014).

As such, the country's capital markets are relatively more developed and integrated with international markets, something that may be fortified by the country's recent incorporation into BRICS economies (an association of five emerging economies, stands for Brazil, Russia, India, China and South Africa) (Chinzara \& Aziakpono, 2009). Hence, it may be relatively easy for South African firms, which follow international accounting standards, to raise capital from international markets. However, South Africa's 'African-ness' cannot be easily shrugged off. It is, to a certain extent, integrated with the rest of Africa and has been touted as the gateway to Africa. For example, South Africa contributes about 20\% to Africa's GDP, and since 1994 the country has intensified its investment into the continent (Grobbelaar, 2004). For example, South African firms like MTN, Standard Bank, Vodacom, ABSA, and Pick n Pay have operations in several African countries. Second, if convergence growth theories hold, South Africa's relatively more developed position on the continent implies that its African counterparts may follow its growth trajectory as they progressively catch up (Ramjee and Gwatidzo, 2012). Therefore, what works in South Africa is more likely to work in other African countries (Ramjee \& Gwatidzo, 2012).

More importantly, testing capital structure theories in developing economies like South Africa enables us to examine the theories in a different and relatively new institutional environment compared to developed countries. If the results are similar to those found in developed economies then that may confirm the applicability of such theories across different environments. The failure of such theories in such environments may point to the need to fine-tune them, or to the development of theories that are more relevant to the African environment (Gwatidzo, 2008:7).

The rest of the study is structured as follows. Section 2 presents a literature review on capital structure determinants. Section 3 discusses the econometric methodology. Section 4 discusses the results, and Section 5 concludes the paper.

\section{LITERATURE REVIEW}

Modigliani and Miller's $(1958,1963)$ seminal contribution on capital structure has two important outcomes. First, under perfect capital markets - with perfect information and no transaction costs - the value of the firm is independent of capital structure. Second, if taxes are introduced in the Modigliani and Miller framework, tax rates and the concomitant interest tax shields become dominant factors in capital structure choice decisions. Ultimately it is possible to get a corner solution, with the firm raising capital using debt only. In reality, when market frictions have been taken into account, firm value becomes a function of capital structure. Moreover, firms tend to have moderate and more cautious debt levels on their balance sheets, and not the extreme, excessive levels suggested by the corner solution. An attempt to better understand how firms raise capital has seen a huge increase in the literature on capital structure. See, for example, Titman and Wessels (1988), Glen and Singh (2004), Booth et al. (2001), Wald (1999), Rajan and Zingales (1995), MacKie-Mason (1990), and Graham (1999). Nevertheless, even though Modigliani and Miller's groundbreaking contribution $(1958,1963)$ saw an exponential growth in the literature on capital structure, there is still no universal theory on capital structure nor is the debate on how firms should raise capital settled. Many studies have thus been conducted trying to test the main 
capital structure theories; the trade-off theory and the pecking order theories. See, for example, Shyam-Sunder and Myers (1999) and Prasad et al. (2001).

According to the trade-off theory (TOT), debt comes with some costs and benefits. On the one hand, debt is beneficial because of tax savings emanating from interest tax deductions. On the other, more debt increases the probability of default. That is, it increases the costs of financial distress, including the costs incurred when a firm is in bankruptcy or under reorganisation. Such costs include legal and administration costs directly related to financial distress, costs of disposing of assets, as well as the costs emanating from the conflicts of interest between debtholders and equity holders. Such conflicts are usually due to an attempt by one group to get a larger share of the fixed payoff as the firm gets liquidated (Myers, 2003).

The pecking order theory (РОT), first introduced by Donaldson in 1961 and modified by Myers and Majluf (1984), states that there is no well-defined target capital structure (Huang and Song, 2006). Because of information asymmetry between insiders (e.g., existing shareholders and the management) and outsiders (e.g., market participants) firms prefer internal to external funds and, when faced with external sources, tend to choose debt over equity; only using equity as a last resort (Myers, 2003). (For studies that support the pecking order theory see, for example, Abor (2008) and Ramjee and Gwatidzo (2012).)

As discussed above, most studies on capital structure are on developed economies, are static in nature and also tend to be mean-based. This paper extends the literature by carrying out a distributional analysis of the determinants of capital structure using a South African panel data set. The following section discusses the main determinants of capital structure.

\subsection{Measures of leverage and determinants of capital structure}

In this section we briefly discuss the different leverage measures as well as the main capital structure determinants suggested by the different theories as well as those found to be important in different empirical studies. We use the long-term debt and total-debt ratios to measure leverage. In both cases the book value leverage measures are used.

Profitability - The two main capital structure theories, trade-off theory (TOT) and pecking order theory (POT), give different results concerning the impact of profitability on leverage. The TOT predicts a positive relationship between leverage and profitability. According to the TOT more profitable firms have more taxable income and must use more debt to shield such income from tax (De Angelo Masulis, 1980; Huang and Song, 2006). Also, more profitable firms are more likely to get loans, as they are more likely to honour their debt obligations (Rajan \& Zingales, 1995; Wiwattanakantang, 1999). The POT predicts a negative relationship between profitability and leverage. According to the POT, more profitable firms prefer internal to external finance. So they tend to use internal finance to fund their investment activities and thus use less external funds (debt). Most studies show a negative relationship between leverage and profitability. See, for example, Ezeoha (2008), Rajan and Zingales (1995), Wald (1999), Booth et al. (2001), Wiwattanakantang (1999). In this paper, we use earnings before interest and tax (EBIT) scaled by total assets to measure profitability.

Asset Tangibility (Tangibility) - Given the inherent conflict of interest between shareholders and debtholders, lenders may demand more collateral to reduce the probability of asset substitution (Chakraborty, 2010). Firms with more tangible assets can pledge such assets as collateral and possibly get loans at lower costs. Also, the greater the collateral the greater the value the lender can recover in the event of default (Jensen \& Meckling, 1976). Firms with less tangible assets have 
lower collateral and may get loans at higher cost; this may discourage them from using more debt. We thus expect a positive relationship between asset tangibility and leverage (Chakraborty, 2010). Studies that find a positive relationship between asset tangibility and leverage include Marsh (1982), Titman and Wessels (1988), Wiwattanakantang (1999) and Booth et al. (2001). In line with the literature, we measure asset tangibility using the ratio of total fixed assets to total assets.

Size - Firm size can be used to proxy for a number of things. For example, larger firms are more visible in the market. Therefore they are associated with lower degrees of information asymmetry. Following the POT, larger firms are associated with less information asymmetry problems and are more likely to use equity - implying an inverse relationship between size and leverage (Myers and Majluf, 1984). The agency problems - asset substitution and underinvestment - which emanate from the conflicts between debtholders and shareholders, are also lower for larger firms. So, larger firms can take more debt without overly worrying about these problems. Larger firms are also associated with less risk, as they are more diversified (Titman and Wessels, 1988), are likely to have more stable cash flows, and are less likely to default. Lenders may thus be more willing to offer such firms more loans more cheaply - implying a positive relationship between size and leverage (Panno, 2003). Most studies in the literature find a positive relationship between leverage and size. See, for example, Rajan and Zingales (1995), Wald (1999), Booth et al. (2001), Wiwattanakantang (1999). In the literature, size is measured using log of sales or total assets or number of employees.

Reputation (Age) - Firms that have not been in existence for a long time lack reputation and cannot easily access external funds (Diamond, 1991). But with time they acquire reputation, which they can use to access cheaper external finance, including debt. It is also well documented in the literature that a significant number of firms are liquidated in the first three years of their existence. Firms that have been in existence for a long time are less risky, as they must have survived various shocks in the course of their existence. Such endurance and the concomitant reputation may enable them to easily access funds in the capital markets. Lenders are thus more likely to be willing to offer them loans. We thus expect a positive relationship between reputation and leverage. We measure age by the number of years since the firm's incorporation. Studies that find a positive relationship between age and leverage include Petersen and Rajan (1994), Ezeoha (2008) and Hall et al. (2004).

Growth opportunities (Growth) - growth opportunities are estimated by the market-to-book value (MTBV) ratio, with market value also capturing growth opportunities, while book value captures only a firm's asset-in-place (Myers, 2003). The higher the MTBV ratio the higher the growth opportunities, since the market value would be much bigger than the book value. From a theoretical point of view, firms with higher growth opportunities tend to borrow less (Myers, 2003). This is because growth opportunities are not tangible assets and cannot be pledged as collateral in securing a loan (Cespedes, 2010; Huang \& Song, 2006). According to Berens and Cuny (1995), firm growth implies significant equity financing. Growth opportunities have been variously measured in the literature. The different measures include: Tobin's Q, MTBV ratio, research and development expenditure scaled by total assets, and capital investment scaled by total assets. In this paper we use the MTBV ratio to measure growth opportunities.

Volatility (Risk) - Volatility in this case measures business risk and assesses the probability of financial distress. For highly risky firms the volatility in cash flows may be so high as to result in the firm failing to honour some of its debt obligations. So, highly risky firms are more likely to default on their payments. Lenders are thus less willing to offer them loans. If they do they are 
more likely to offer them at high interest rates, or at punitive terms. Firms with less risk are more likely to cheaply access debt. We thus expect a negative relationship between risk and leverage. Studies that find a negative relationship between volatility and leverage include Booth et al. (2001) and Wald (1999). In the literature the standard deviation of the return on assets (ROA) has been used to measure risk (Booth et al., 2001).

Tax - According to the trade-off theory, firms can use more debt to shield their incomes from tax (Abor, 2008). This is especially important if tax rates are high - firms facing higher tax rates tend to use more debt to gain from tax shields (De Angelo Masulis, 1980; Huang \& Song, 2006). Studies that argue that financing decisions are affected by taxes include MacKie-Mason (1990) and Graham (1999). We measure the tax rate using the ratio of tax paid to earnings before interest and tax.

\section{METHODOLOGY AND DATA}

The study estimates conditional quantiles of leverage for firm $i$ in period $t\left(y_{i t}\right)$ following Canay (2011). This entails specifying equation (1).

$$
y_{i t}=\mathbf{X}_{i t}^{\prime} \theta\left(U_{i t}\right)+\alpha_{i}
$$

where $\mathrm{t}=1 \ldots \ldots . \mathrm{T} ; \mathrm{i}=1 \ldots \ldots . ., \mathrm{n} ; \mathrm{X}_{i t}$ is a vector of predictor variables for firm $i$ in period $t$ including: age, firm-size, profit, asset tangibility, growth, risk and tax. $U_{i t}$ and $\alpha_{i}$ are unobservable variables. $\alpha_{i}$ captures fixed effects which are perceived as location shift variables - the effects are assumed to be constant across all quantiles. This assumption is justifiable because of fixed firm characteristics and country properties across time.

Let $\tau \in(0,1)$ denote quantiles of the distribution of firm leverage such that the function $X^{\prime} \theta(\tau)$ strictly increases in $\tau$. We are interested in estimates of $\theta(\tau)$ i.e. heterogeneous effects of regressors on $y_{i t}(\tau) ; \theta(\tau) . \theta(\tau)$ is estimated in two steps. The first step estimates $\hat{\alpha}_{i}$ using mean regression-based estimators such as OLS in first differences. This follows the assumption that $\hat{\alpha}_{i}$ is constant across all quantiles - pure location shifters. The second step utilises $\hat{\alpha}_{i}$ to obtain measures of firm leverage that are purged of fixed effects $\hat{y}_{i t}: \hat{y}_{i t}=y_{i t}-\hat{\alpha}_{i} \cdot \hat{y}_{i t}$ will then be regressed on covariates, using panel quantile regression methods, to obtain $\hat{\theta}(\tau)$. The following equation gives the empirical model to be estimated:

$$
\text { Leverage }_{i t}=F_{i t}(\text { Tangibility, Tax, Profitability, Volatility, Size, Age, Growth })+e_{i t}
$$

The dependent and predictor variables are as defined in TABLE $A l$ in the appendix. As regards data, we used a firm-level unbalanced panel dataset, comprising $239 \mathrm{JSE}$-listed firms spanning from 1996-2010. Companies that had at least three years of data points were included in the sample. We excluded firms that are in the financial services, as they are subject to a different regulatory authority and have different capital structures to non-financial firms. Using the USSIC industry classification code, firms in the regions of 01-5999 and 7001-8999 were selected. All our data was obtained from Bureau Van Dijk's OSIRIS database. TABLE A2 in the appendix also shows the descriptive statistics for the firms in the sample. The table shows that, just like other firms in Africa, South African firms tend to use more short-term debt (0.36) than long-term debt (0.16). TABLE 1 also shows the correlation matrix. In all cases the correlation coefficients are quite low (less than 0.40 ), suggesting minimal autocorrelation among variables. 
TABLE 1: Correlation Matrix

\begin{tabular}{lccccccc}
\hline & $\begin{array}{c}\text { Profita- } \\
\text { bility }\end{array}$ & $\begin{array}{c}\text { Tangibi- } \\
\text { lity }\end{array}$ & Size & Taxation & Risk & Growth & Age \\
\hline Profitability & 1 & & & & & \\
Tangibility & $-0.06 *$ & 1 & & & & \\
Size & $-0.1 *$ & $0.33^{*}$ & 1 & & & \\
Taxation & 0.03 & $0.16 *$ & 0.02 & 1 & 1 & \\
Volatility & $0.29 *$ & -0.04 & -0.03 & $0.08 *$ & 1 & \\
Growth & 0.04 & 0.02 & -0.03 & 0.01 & $0.31 *$ & 1 \\
Age & -0.02 & $0.09 *$ & $0.24 *$ & -0.01 & -0.04 & $-0.13 *$ \\
\hline
\end{tabular}

Source: Authors' analysis

Notes: Standard errors in brackets * significant at $10 \%$; $* \star$ significant at $5 \%$; $* \star \star$ significant at $1 \%$

\section{DISCUSSION OF RESULTS}

The results of the study are presented in TABLES 2 and 3, which respectively present total-debt and long-term debt ratios as leverage measures. FIGURES 1 and 2 show the impact of predictor variables on leverage across the distributions. TABLE 1 shows the correlation matrix of the variables used in the study.

The results are reported at the $10^{\text {th }}, 25^{\text {th }}, 50^{\text {th }}, 75^{\text {th }}$ and $90^{\text {th }}$ quantiles $(\rho)$ of the leverage distributions. In line with the POT, we find a negative and significant relationship between profitability and leverage. When using long-term debt the profitability parameter is significant only at the $50^{\text {th }}$ quantile (at the $10 \%$ level). When using total-debt ratio the profitability parameter is significant at all quantiles, with the exception of the $90^{\text {th }}$ quantile. More importantly, we also investigate whether the impact of the different predictor variables varies across quantiles. We find that the effect of profitability on leverage is statistically similar across quantiles, as is shown by the F-test in the last columns of TABLES 2 and 3. This implies that a unit change in profitability has similar effects on lowly levered and highly levered firms. The negative relationship between leverage and profitability corroborates findings by Rajan and Zingales (1995), Wald (1999), Booth et al. (2001), and Wiwattanakantang (1999).

We expected a positive relationship between asset tangibility and leverage. This is in line with the notion that firms with more fixed assets tend to have high collateral to pledge, thus acquiring more debt. In a majority of cases, we found this to be the case. For example, the findings for longterm debt in TABLE 3 show a positive and significant relationship between asset tangibility and leverage across all quantiles. The findings of the F-test show that the effect of this predictor variable differs across the leverage quantiles. It accelerates across the distribution - it is lower for lowly-levered and higher for highly-levered firms. A unit increase in asset tangibility increases long-term debt by 0.21 units at the $10^{\text {th }}$ quantile and 0.36 at the $90^{\text {th }}$ quantile. Thus, the effect of asset tangibility increased by $75 \%$ from the $10^{\text {th }}$ to the $90^{\text {th }}$ quantile. When using the total-debt specification we found mixed results; the relationship is negative and significant at the $10^{\text {th }}$ quantile but positive at the $75^{\text {th }}$ quantile. 
TABLE 2: Results when using Total Debt Ratio (TDR) as the Dependent Variable

\begin{tabular}{|c|c|c|c|c|c|c|}
\hline & & & & & \multicolumn{2}{|c|}{$\operatorname{Test}(\rho 10=025=050=075=090)$} \\
\hline & Q10 & Q25 & Q50 & Q75 & Q90 & $F(4,868)$ \\
\hline \multirow[t]{2}{*}{ Profitability } & $-0.160 * *$ & $-0.152 * \star \star *$ & $-0.124 * \star \star *$ & $-0.139 * *$ & 0.007 & 1.09 \\
\hline & {$[0.064]$} & {$[0.031]$} & {$[0.033]$} & {$[0.059]$} & {$[0.089]$} & \\
\hline \multirow[t]{2}{*}{ Tangibility } & 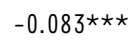 & -0.018 & 0.011 & $0.030 *$ & 0.016 & $3.41 * \star \star$ \\
\hline & {$[0.029]$} & {$[0.019]$} & {$[0.016]$} & {$[0.018]$} & {$[0.036]$} & \\
\hline \multirow[t]{2}{*}{ Size } & $0.016 \star \star \star$ & $0.017 \star \star \star$ & $0.016 * \star \star$ & $0.015 * \star \star$ & $0.018 * \star \star$ & 0.31 \\
\hline & {$[0.004]$} & {$[0.002]$} & {$[0.002]$} & {$[0.002]$} & {$[0.004]$} & \\
\hline \multirow[t]{2}{*}{ Tax } & $-0.178 * \star \star$ & $-0.225 \star \star \star$ & 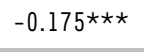 & 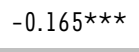 & $-0.178 \star \star \star$ & 0.85 \\
\hline & {$[0.052]$} & {$[0.039]$} & {$[0.033]$} & {$[0.040]$} & {$[0.055]$} & \\
\hline \multirow[t]{2}{*}{ Volatility } & 0.007 & $0.013 \star \star$ & $0.011 * \star$ & $0.013 * *$ & 0.012 & 0.3 \\
\hline & {$[0.010]$} & {$[0.005]$} & {$[0.005]$} & {$[0.005]$} & {$[0.009]$} & \\
\hline \multirow[t]{2}{*}{ Growth } & 0.007 & 0.007 & 0.011 & 0.01 & 0.017 & 0.14 \\
\hline & {$[0.014]$} & {$[0.010]$} & {$[0.011]$} & {$[0.015]$} & {$[0.016]$} & \\
\hline \multirow[t]{2}{*}{ Age } & -0.001 & $-0.011 * \star \star *$ & -0.002 & 0.004 & 0.001 & $0.2^{*}$ \\
\hline & {$[0.009]$} & {$[0.004]$} & {$[0.004]$} & {$[0.007]$} & {$[0.008]$} & \\
\hline \multirow[t]{2}{*}{ Constant } & $0.300 * \star \star$ & $0.337 * \star \star *$ & $0.347 * \star \star$ & $0.385 * \star \star$ & $0.389 * \star \star$ & \\
\hline & {$[0.051]$} & {$[0.026]$} & {$[0.025]$} & {$[0.031]$} & {$[0.060]$} & \\
\hline Observations & 876 & 876 & 876 & 876 & 876 & \\
\hline
\end{tabular}

Source: Authors' analysis

Notes: Standard errors in brackets, * significant at $10 \%$; $*$ significant at $5 \%$; $* \star *$ significant at $1 \%$

The importance of firm size in capital markets cannot be overemphasised. Size can be used as a proxy for the level of information asymmetry as well as reputation. Larger firms are associated with lower levels of information asymmetry and tend to have some vast reputation to protect. Larger firms therefore know that the market is watching and must therefore protect such reputation by honouring their debt obligations. Larger firms may also get involved in large projects, which require more than their internally generated finance - hence the need to borrow in the debt market. The need to borrow as well as the willingness of the lenders to extend credit to larger firms are important factors that contribute to the positive relationship between leverage and firm size. We therefore expected a positive relationship between firm size and leverage. Our results confirm this hypothesis. Firm size is found to be positively and significantly (at the $1 \%$ level across all quantiles) related to both long-term debt and total-debt ratios. The estimated parameters are more or less the same across the quantiles, suggesting that the effect of size does not seem to be changing across the quantiles. This implies that even though size matters, it has the same effect for both lowly-levered and highly-levered firms. 
TABLE 3: Results when using Long Term Debt Ratio (LTR) as the Dependent Variable

\begin{tabular}{|c|c|c|c|c|c|c|}
\hline & & & & & \multicolumn{2}{|c|}{$\operatorname{Test}(\rho 10=\rho 25=\rho 50=\rho 75=\rho 90)$} \\
\hline & Q10 & Q25 & Q50 & Q75 & Q90 & $F(4,868)$ \\
\hline \multirow[t]{2}{*}{ Profitability } & -0.03 & -0.02 & $-0.032^{\star}$ & 0.02 & 0.02 & 0.93 \\
\hline & {$[0.059]$} & {$[0.029]$} & {$[0.018]$} & {$[0.038]$} & {$[0.041]$} & \\
\hline \multirow[t]{2}{*}{ Tangibility } & $0.208 * \star \star$ & $0.263 * \star \star *$ & $0.307 * \star \star$ & $0.337 * \star \star$ & $0.364 * \star \star$ & $6.2 * \star \star$ \\
\hline & {$[0.026]$} & {$[0.017]$} & {$[0.011]$} & {$[0.015]$} & {$[0.034]$} & \\
\hline \multirow[t]{2}{*}{ Size } & $0.025 \star \star \star$ & $0.026 \star \star \star$ & $0.026 \star \star \star$ & $0.029 \star \star \star$ & $0.032 \star \star \star$ & 1.00 \\
\hline & {$[0.003]$} & {$[0.001]$} & {$[0.001]$} & {$[0.002]$} & {$[0.004]$} & \\
\hline \multirow[t]{2}{*}{ Tax } & $-0.137 \star \star \star$ & $-0.125 \star \star \star$ & $-0.144 \star \star \star$ & $-0.139 \star \star \star$ & $-0.114^{\star}$ & 0.30 \\
\hline & {$[0.036]$} & {$[0.029]$} & {$[0.019]$} & {$[0.029]$} & {$[0.062]$} & \\
\hline \multirow[t]{2}{*}{ Volatility } & 0.01 & 0.00 & 0.01 & 0.00 & 0.00 & 0.21 \\
\hline & {$[0.007]$} & {$[0.003]$} & {$[0.003]$} & {$[0.005]$} & {$[0.009]$} & \\
\hline \multirow[t]{2}{*}{ Growth } & 0.00 & 0.00 & 0.00 & 0.01 & 0.03 & 0.78 \\
\hline & {$[0.008]$} & {$[0.005]$} & {$[0.006]$} & {$[0.009]$} & {$[0.023]$} & \\
\hline \multirow[t]{2}{*}{ Age } & $-0.014 * \star$ & 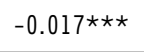 & $-0.013 * \star \star \star$ & 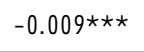 & 0.00 & 1.99 \\
\hline & {$[0.007]$} & {$[0.003]$} & {$[0.002]$} & {$[0.003]$} & {$[0.007]$} & \\
\hline \multirow[t]{2}{*}{ Constant } & 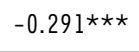 & $-0.288 * \star \star \star$ & 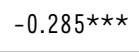 & $-0.321 * \star \star *$ & 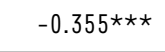 & \\
\hline & {$[0.033]$} & {$[0.021]$} & {$[0.015]$} & {$[0.026]$} & {$[0.051]$} & \\
\hline Observations & 876.00 & 876.00 & 876.00 & 876.00 & 876.00 & \\
\hline
\end{tabular}

Source: Authors' analysis

Notes: Standard errors in brackets, * significant at $10 \%$; $*$ significant at $5 \%$; $* \star *$ significant at $1 \%$.

Concerning the relationship between tax and leverage, we find a negative relationship across quantiles. Taxation also has a larger effect at the top than at the bottom of the leverage distribution. This suggests that taxation makes a big difference to the capital structure of firms with more debt than for those with low debt levels. The estimated parameters are somewhat similar across quantiles, suggesting that the effect of tax is robust across quantiles. This negative relationship between tax and leverage, however, contradicts the TOT, which suggests that firms use more debt to finance their activities to increase the benefits of tax shields. Nonetheless, this result accords with those of Negash (2002) and Ramjee and Gwatidzo (2012).

TABLES 2 and 3 also exhibit a positive relationship between risk (volatility) and leverage. When using the total-debt measure of leverage, the relationship is positive and significant in the $25^{\text {th }}$, $50^{\text {th }}$ and $75^{\text {th }}$ quantiles. The F-test results show that the variable's effect is statistically similar across quantiles. As such, a unit increase in risk increases leverage by $0.011-0.013$ units at the $25^{\text {th }}-75^{\text {th }}$ quantiles. The positive relationship between risk and leverage is surprising, as we expected riskier firms to have less debt. This can be rationalised by the notion that riskier firms may be heavily penalised in the equity market. Hence they may resort to debt-financing (especially bank debt). A further explanation is that our risk measure, calculated as the rolling standard deviation, may not be accurately capturing firm risk. The findings also reveal a positive 
but statistically insignificant relationship between both measures of leverage and firm growth, across all specifications and quantiles.

With regard to age - a measure of reputation - we expect a negative correlation between age and leverage. As such, older firms tend to be listed on stock exchanges and can issue more equity to finance their activities. The finding in the model for long-term debt ratio exhibits that age has a negative and statistically significant effect on leverage, except for the $90^{\text {th }}$ quantile. This negative outcome suggests that older firms tend to be lowly-levered than younger ones. This partly arises because old firms are endowed with reputation in the capital market, qualifying them for cheaper funds therefrom. The above finding only applies to the $25^{\text {th }}$ quantile of the distribution for total debt ratio; it is insignificant in remaining quantiles. It is noteworthy that our negative finding is opposite to those of Petersen and Rajan (1994), Ezeoha (2008) and Hall et al. (2004).

\section{CONCLUSION}

This paper investigates the effect of a number of predictor variables on leverage. Its main contribution is to assess the effect of the variables at different quantiles of leverage. That is, are the determinants more important at higher than lower levels of leverage? With the exception of asset tangibility and age, whose impact increased with leverage, our results suggest that the importance of leverage determinants does not change with leverage. This is an important result, as it suggests that for the case of South Africa, studies that estimate the impact at the mean are still valid and appropriate.

Other than the importance of the different factors across the quantiles, we also find evidence in support of a number of different capital structure theories. For example, the negative relationship between profitability and leverage is a robust confirmation of the pecking order theory. The positive relationship between asset tangibility and leverage, as well as between firm size and leverage, suggests that even in South Africa, where the capital markets are relatively more developed than those of other African countries, collateral and firm visibility play important roles in mitigating the effects of information asymmetry in debt markets. The negative relationship between age and leverage is in line with the reputation-acquisition notion a la Diamond (1991). According to Diamond, firms acquire some reputation with age, and they use such reputation to acquire cheaper sources of finance. To the extent that the South African arms-length debt market is not well developed, the firms may find it cheaper to acquire external finance from other sources other than debt, implying a negative relationship between leverage and age. This may be particularly aimed at avoiding the implicit taxes associated with bank loans. In South Africa such implicit taxes may be high given the lack of competition in the country's banking sector. We also find a negative relationship between taxation and the two leverage measures. Growth opportunities were found to be unimportant across the different quantiles and specifications. We find a positive relationship between risk and leverage, suggesting that banks, the main source of debt in South Africa, may be competing for clients and may be offering riskier firms loans. Such riskier firms may actually be avoiding issuing equity in the capital markets, since this may also be more expensive given their levels of risk.

In conclusion, it should be observed that one limitation of the study is measuring risk by rolling standard deviation of ROA, which may not be the most appropriate measure. Also, although size measures market visibility, and therefore the extent of information asymmetry, and age measures reputation, it must be pointed out that size may be related to age, as most large firms are older firms. 


\section{LIST OF REFERENCES}

Abor, J. (2008). Agency theoretic determinants of debt levels: Evidence from Ghana. Review of Accounting and Finance, 7(2), pp. 183-192.

Abor, J. \& Biekpe, N. (2005). What determines the capital structure of listed firms in Ghana? African Finance Journal, 7, pp. 37-48.

Allen, F., Carletti, E., Cull, R., Qian, J., Senbet, L. \& Valenzuela, P. (2014). The African financial development and financial inclusion gaps. Journal of African Economies, 23 (5), pp. 614-642.

Byoun, S. (2008). How and when do firms adjust their capital structures towards targets? Journal of Finance, 63(6), pp. 3069-3096.

Booth, L., Aivazian, V., Demigurc-Kunt, A. \& Maksimovic, V. (2001). Capital structure in developing countries. The Journal of Finance, 56, pp. 87-130.

Canay, I. (2011). A simple approach to quantile regression to panel data. The Econometrics Journal, 14(3), pp. 368-386.

Chinzara, Z. \& Aziakpono, M. (2009). Integration of the South Africa equity market into the world major stock markets: Implication for portfolio diversification. The African Finance Journal, Special Issue, pp. 95-119.

Diamond, D. (1991). Monitoring and reputation: the choice between bank loans and directly placed debt. Journal of Political Economy, 99, pp. 689-721.

De Angelo, H. \& Masulis, R. (1980). Optimal capital structure under corporate and personal taxation. Journal of Financial Economics, 7, pp. 3-29.

Drobetz, W., \& Wanzenried, G. (2006). What determines the speed of adjustment to the target capital structure? Applied Financial Economics, 16, 941-958.

Ezeoha, A.E. (2008). Firm size and corporate financial leverage choice in a developing economy: Evidence from Nigeria. The Journal of Risk Finance, 9, pp. 351-364.

Fatouh, B., Scaramozzino, P. \& Harris, L. (2005). Capital structure in South Korea: A quantile regression approach. Journal of Development Economics, 76, pp. 231-250.

Flannery, M.J. \& Rangan, K.P. (2006). Partial adjustment toward target capital structures. Journal of Financial Economics, (79), pp. 469-506.

Frank, M. \& Goyal, V. (2003). Testing the pecking order theory of capital structure. Journal of Financial Economics, (67), pp. 217-248.

Graham, J. R. (1996). Debt and the marginal tax rate. Journal of Financial Economics, 41, pp. 41-73.

Green, C., Murinde, V. \& Suppakitjarak, J. (2002). Corporate financial structures in India.

Loughborough University, Economics Department Research Paper No. 02/4.

Grobbelaar, N. (2004). Can South Africa business drive regional integration on the continent? South African Journal of International Affairs, 11(2), pp. 91-106.

Gwatidzo, T. (2008). The determinants of capital structure in Sub-Saharan Africa. Unpublished PhD manuscript. Johannesburg, University of the Witwatersrand.

Gwatidzo, T. \& Ojah, K. (2009). Corporate capital structure determinants: evidence from five African countries. African Finance Journal, 11(1), pp. 1-23. 
Glen, J. \& Singh, A. (2004). Comparing capital structures and rates of return in developed and emerging markets. Emerging Markets Review, 5, pp. 161-192.

Graham, J.R. (1999). Do personal taxes affect corporate financing decisions? Journal of Public Economics, 73, pp. 41-73.

Green, C.J., Kimuyu, P., Manos, R. \& Murinde, V. (2007). How do Small Firms in Developing Countries Raise Capital? Evidence from a Large-Scale Survey of Kenyan Micro and Small-Scale Enterprises. In M. Hirschey, K. John \& A.K. Makhija (eds.) Issues in Corporate Governance and Finance (Advances in Financial Economics, Volume 12), Emerald Group Publishing Limited, pp. 379-404.

Haas, R. \& Peeters, M. (2006). The dynamic adjustment towards target capital structures of firms in transition economies. Economics of Transition, 14(1), pp. 133-169.

Huang, G. \& Song, F.M. (2006). The determinants of capital structure: Evidence from China. China Economic Review, 17, pp. 14-36.

Hovakimian, A. \& Li, G. (2010). Is the Partial Adjustment Model a Useful Tool for Capital Structure Research? Review of Finance (2010), pp. 1-22.

Hall, G.C., Hutchinson, P.J. \& Michaelas, N. (2004). Determinants of the capital structures of European SMEs. Journal of Business Finance and Accounting, 31 (5/6), pp. 711-28.

Hovakimian, A. \& Li, G. (2011), In search of conclusive evidence: how to test for adjustment to target capital structure? Journal of Corporate Finance, 17, pp. 33-44.

Heinkel, R. \& Zechner, J. (1990). The role of debt and preferred stock as a solution to adverse investment incentives. The Journal of Financial and Quantitative Analysis, 25, pp. 1-24.

Jooma, M.Y.H. \& Gwatidzo, T. (2013). Partial adjustment toward target capital structure: Evidence from selected African countries. Journal of Corporate Ownership and Control, 10(3), pp. 386-401.

Jensen, M.C. \& Meckling, W.H. (1976). Theory of the firm: managerial behaviour, agency costs and the ownership structure. Journal of Financial Economics, 3, pp. 305-360.

Koenker, J. (2004). Quantile Regression for Longitudinal data. Journal of Multivariate Analysis, 91, pp. 74-89.

Mackie-Mason, J.K. (1990). Do taxes affect financing decisions? Journal of Finance, 45, pp. 1471-1493.

Modigliani, F. \& Miller, M. (1958). The cost of capital, corporation finance and the theory of investment. American Economic Review, (48), pp. 361-297.

Modigliani, F. \& Miller, M. (1963). Corporate income taxes and the cost of capital: A correction. American Economic Review, (53), pp. 433-443.

Mackie-Mason, J.K. (1990). Do taxes affect financing decisions? Journal of Finance, (45), pp. 14711493.

Myers, S.C. (2003). Financing corporations. In Handbook of the Economics of Finance (Vol. 1.A). New Holland, Amsterdam: Elsevier.

Myers, S.C \& Majluf, N.S. (1984). Corporate financing and investment decisions when firms have information that investors do not have. Journal of Financial Economics, 13, pp. 187-221.

Marsh, P. (1982). The choice between equity and debt: An empirical study. Journal of Finance, 37, pp. 121-144. 
Negash, M. (2002). Debt, tax shield and bankruptcy costs: Some evidence from JSE. The Investment Analysts Journal, South Africa, 54, pp. 33-44.

Nunkoo, P.K. \& Boateng, A. (2010), "The empirical determinants of target capital structure and adjustment to long run-target: evidence from Canadian firms". Applied Economics, 17, pp. 983-990.

Prasad, S., Green, C., \& Murinde, V. (2001). Corporate structures in developing economies: evidence from a comparative analysis of Thai and Malay corporations. Finance \& Development Research Programme.

Petersen, M.A. \& Rajan, R.G. (1994). The benefits of lending relationships: Evidence from small business data. The Journal of Finance, 49(1), pp. 3-38.

Prasad, S., Green, C. \& Murinde, V. (2001). Corporate structures in developing economies: Evidence from a comparative analysis of Thai and Malay corporations. Finance and Development Research Programme. Institute of Development Policy and Management Working Paper Number 35.

Rajan, G.R. and Zingales, L. (1995). What do we know about capital structure? Some evidence from international data. Journal of Finance, 50, pp. 1421-1460.

Ramjee, A., \& Gwatidzo, T. (2012). Dynamics in capital structure determinants in South Africa. Meditari Accountancy Research, 20(1), pp. 52-67.

Reinhard, L. \& Li, S. (2010). A note on capital structure target adjustment - Indonesian evidence, International Journal of Managerial Finance, 6(3), pp. 245-59.

Shyam-Sunder, L., \& Myers, S. (1999). Testing static trade-off against pecking order models of capital structure. Journal of Financial Economics, (51), pp. 219-244.

Titman, S., \& Wessels, R. (1988). The determinants of capital structure choice. Journal of Finance, (43), p. 1019.

Wiwattanakantang, Y. (1999). An empirical study of the determinants of capital structure in Thai firms. Pacific-Basin Finance Journal, 7, pp. 371-403.

Wald, J. (1999). How firm characteristics affect capital structure: an international comparison. Journal of Financial Research, 22, pp. 161-187.

Yeh, H.H. (2011), Adjustment behaviour of capital structure over the business cycles: evidence from the construction industry of Taiwan, Construction Management and Economics, 2, pp. 329-340. 


\section{Appendix}

rin.1a

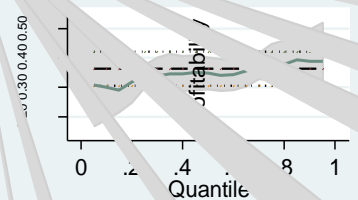

Fig 'd

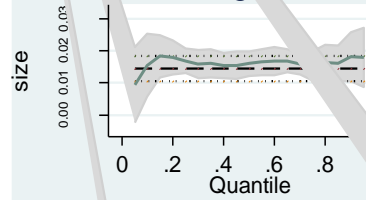

Fig.1g
Fig.1b

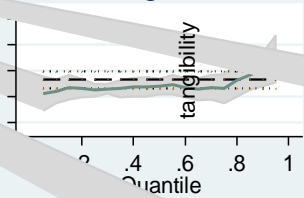

Fig. I

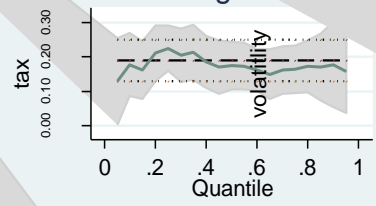

Fig.1h
Fig.1c

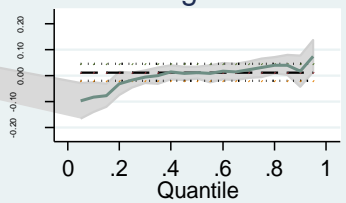

Fig.1f
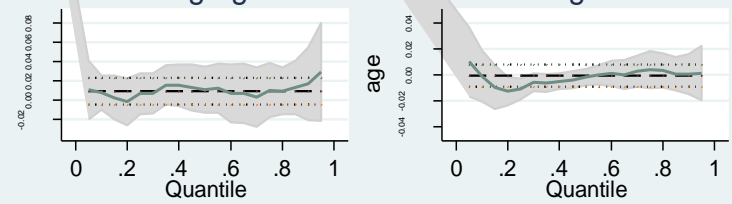

FIGURE 1: Plots of coefficients over quantiles for total-debt ratio (TDR) 


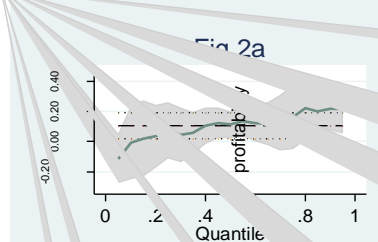

Fin $2 h$
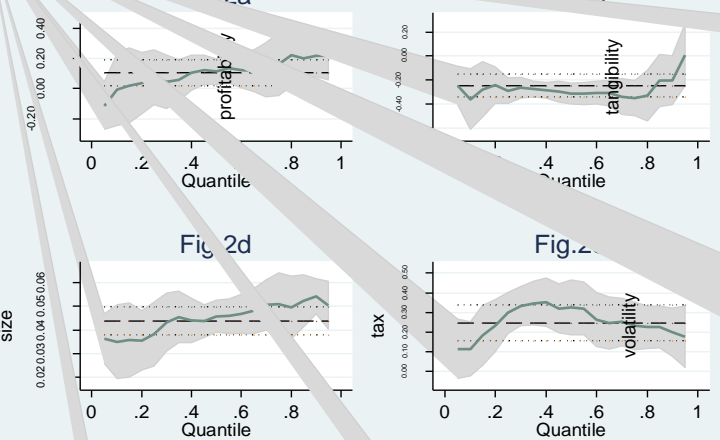

Fig. $2 \mathrm{~g}$

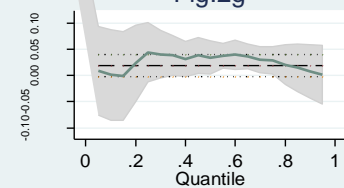

Fig.c

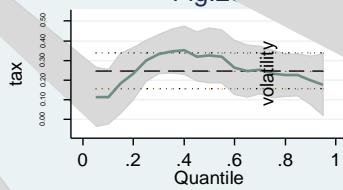

Fig.2h

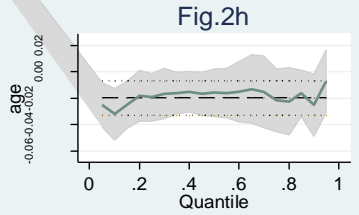

Fig.2c

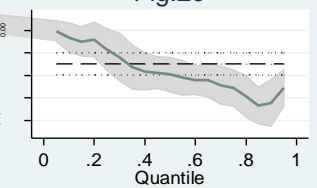

Fig.2f

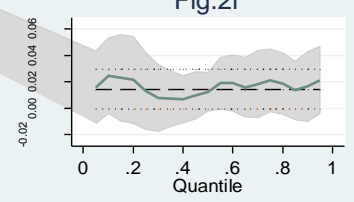

FIGURE 2: Plots of coefficients over quantiles for long-term debt ratio (LDR) 
Gwatidzo, Ntuli \& Mlilo

TABLE A1: Variables and their definitions

\begin{tabular}{ll}
\hline Variable & Variable Definition \\
\hline TDR & Total liabilities divided by total assets (total assets are measured using book value). \\
LTR & Long term liabilities divided by total assets \\
Tangibility & Total fixed assets divided by total assets \\
Tax & Income tax paid divided by earnings before interest and tax (EBIT) \\
Profitability & EBIT divided by total fixed assets \\
Volatility & Five year rolling standard deviation of profitability \\
Size & Natural log of total assets \\
Age & Age is defined as the natural log of the number of years since the company was found. \\
Growth & Market-to-book value ratio \\
\hline
\end{tabular}

TABLE A2: Descriptive statistics

\begin{tabular}{ccccccccccc}
\hline & TDR & LTR & STR & $\begin{array}{c}\text { Profita } \\
\text { bility }\end{array}$ & $\begin{array}{c}\text { Tangi- } \\
\text { bility }\end{array}$ & Size & Tax & Risk & Growth & Age \\
\hline Min & 0.011 & 0 & 0.001 & 0.002 & 0 & 4.868 & -0.92 & -4.202 & -4.021 & 0 \\
Max & 9.338 & 1.882 & 9.338 & 14.027 & 0.996 & 18.997 & 0 & 3.961 & 9.728 & 3.434 \\
$\begin{array}{c}\text { Std. } \\
\text { Dev }\end{array}$ & 0.278 & 0.15 & 0.273 & 0.378 & 0.223 & 1.977 & 0.129 & 0.765 & 0.501 & 0.869 \\
Mean & 0.52 & 0.164 & 0.357 & 0.167 & 0.458 & 14.006 & -0.271 & 0.168 & 0.177 & 2.073 \\
\hline
\end{tabular}

Notes: TDR=total debt ratio, LTR=long-term debt ratio, and STR=short-term debt ratio 